\title{
Allellopathic potential of invasive Psidium guajava L., against selected native tree species in Kakamega Tropical Forest, Western Kenya.
}

\author{
Kawawa, R.C.A ${ }^{1 *}$., Obiri, J.F. ., Muyekho F. $\mathrm{N}^{1}$.,Omayio, D.O ${ }^{1}$., Agevi, $\mathrm{H}^{1}$., \\ Mwaura, ${ }^{3}$., Obiet, $L^{1}$., Kimutai, D. $K^{4}$., and Sifuna A. ${ }^{1}$ \\ ${ }^{l}$ Department of Biological Sciences; Masinde Muliro University of Science and Technology (MMUST) \\ P.O. Box 190-50100, Kakamega, Kenya. \\ ${ }^{2}$ Centre for Disaster Management and Humanitarian Assistance (CDMHA); Masinde Muliro University of \\ Science and Technology (MMUST), \\ P.O. Box 190-50100, Kakamega, Kenya. \\ ${ }^{3}$ Boidiversity, Research \& Monitoring Division; Kenya Wildlife Services \\ P.O Box 879, Kakamega, Kenya. \\ ${ }^{4}$ Graduate school of Environmental Earth Science, Hokkaido University, Sapporo, Japan. \\ North 10, west 5, Sapporo, Hokkaido 060-0810 \\ * Correspondence author: rashidcalvince@yahoo.com
}

\begin{abstract}
Studies have previously attributed P. guajava invasiveness to its aggressive regeneration and profuse seeding. This study, however verified that its allellopathic influence on native plant species also plays an important role in its invasiveness. Extracts from green fresh and brown dry leaves were concentrated to 20\%, $10 \%$ and $5 \%$ with distilled water used as control. Seeds from Markhamia lutea, Diospyros mespiliformis, Cordia africana and Croton megalocarpus; common native species in Kakamega forest, were treated with these extracts in a completely randomised design to determine the extracts impact on their germination, shoot and root elongation. Experiments were replicated 3 times. The two extracts significantly inhibited seed germination, shoot and root length elongation in C. megalocarpus and in C. africana, while in M. lutea and D. mespiliformis the differences were not significant. The study indicated that the inhibitory effect was concentration dependant and was more pronounced at a higher concentration. P. guajava has allellochemicals inherent in it which inhibits germination and growth of some natives species. Its invasion of the forest can be mitigated partly by planting resistant trees species like $M$. lutea and D. mespiliformis, which exhibited resistance to its allelopathic suppression.This study is significant as it will help reduce spread of P. guajava within Kakamega Forest, and can also be replicated in other similar forests in the world with problems of invasion.
\end{abstract}

Keywords: Allellopathy, Psidium guajava, species invasiveness, forest management, tropical forest.

\section{Introduction}

Tropical forests have been reported to be the world's most complex ecosystems (Naturwissenschaft, 2011). They provide habitat for more than half of the world's known terrestrial plants and animal species (Althof, 2005), despite occupying only seven percent of the total land area (Wakjira, 2006). Biological invasions have increased rapidly throughout the world during the present century and is responsible for the homogenization of floras causing a substantial threat to ecological integrity and biological diversity of native habitats (Obiri et al., 1998). Kakamega tropical forest harbors immense and unique biodiversity (Mbuvi et al., 2009). About 10-20\% of species found in it are endemic (Kiplagat et al., 2008). Its high biodiversity enables it provide various ecological services as elaborated by Kiefer \& Bussman, (2008). The forest can only sustain the provision of these services, when it has a stable biodiversity. However, the Forest has been invaded by various invasive species, with Psidium guajava L., being recorded to be the most significant (KIFCON, 1994). It has distinctive traits which makes it easily identifiable, these traits include; thin, smooth, copper-colored bark that flakes off, showing a greenish layer beneath (Chollom et al., 2012). It has been listed as an aggressive invasive plant species (GISD, 2010). According to the findings of Chapla \& Campos (2010), P. guajava modify habitats, alter ecosystem services and functions, crowds out and replaces native species. Its ability to successfully invade various ecosystems is attributed to its capacity to germinate under various physical conditions, the dispersion of its seeds aided by avian and mammalian vectors (Chollom et al., 2012), ability to store its seeds deeper in soil (Kawawa et al., 2016) and allelopathy (Kawawa et al., 2016;Wang et al., 2015; Chapla and Campos, 2010). Allelopathy is defined as a phenomenon in which one plant affects another through release of chemicals into the environment (Zhao-hui et al., 2010). Allelochemicals produced by invasive plants have been documented to 
inhibit the growth of native species thereby providing the invader with competitive advantage (Ridenour \& Callaway, 2001).

Elsewhere, a number of studies have investigated allelopathic potential of $P$. guajava against various species, Bovey and Diaz-Colon, (1969);Brown et al., (1983);Chapla \& Campos (2010). However, there exists no documented knowledge on $P$. guajava allelopathic potential against the native tree species in Kakamega forest despite its successful invasion and pressures on forest biodivesity. In this study, we investigated the allelopthic potential of $P$. guajava against the four selected common native tree species in Kakamega Forest namely: Cordia africana [Lam], Diospyros mespiliformis [Hochst. Ex DC], Croton megalocarpus [Hutch], and Markhamia lutea [Benth]. We hypothesized that the allelochemicals inherent in P. guajava do not affect the germination, shoot and root elongation of native plant species in Kakamega tropical forest. The findings of this research will provide more information about the strategies used by $P$. guajava to out-compete native species in Kakamega forest. Identification of any native species, exhibiting resistance to allecochemicals inherent in $P$. guajava, will be of great significance to forest managers and conservationists, as such native plants could be planted as potential competitors to minimize $P$. guajava invasion and threat on biodiversity.

\subsection{Collection of $P$. guajava leaves}

\section{Materials and Methods}

Psidium guajava leaves were collected from Kakamega tropical forest, Western Kenya. The forest lies between longitudes $34^{\circ} 40^{\prime}$ and $34^{\circ} 57^{\prime} 30^{\prime \prime}$ East and $0^{\circ} 15^{\prime}$ 'South. It has a varied topography with altitudes ranging from 1250 to $2000 \mathrm{~m}$ above sea level (Vuyiya et al., 2014).Temperature range from $18^{\circ} \mathrm{C}$ to $29^{\circ} \mathrm{C}$ with minima of $11^{\circ} \mathrm{C}$ to $12^{\circ} \mathrm{C}$ (Kiefer \& Bussman, 2008). The annual rainfall show high variation averaged at $2007 \mathrm{~mm}$ over a recent 19-year period (Mammides et al., 2008).

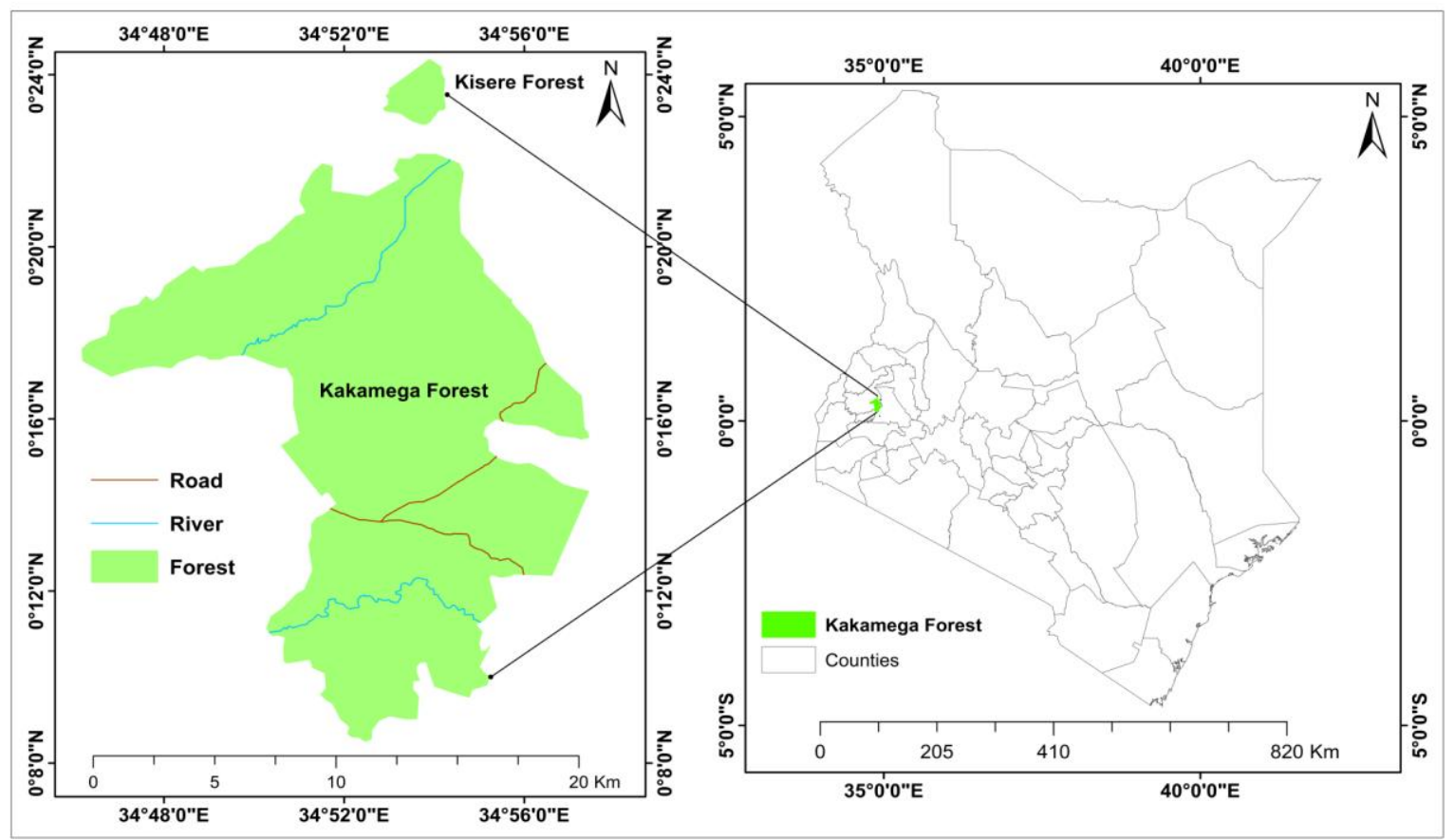

Figure 1: Map of Kakamega Forest.

\subsection{Preparation of the extracts of $P$. guajava leaves}

The plant materials consisted of green fresh leaves attached to the plant and the brown dry leaves fallen to the ground. Each category of leaves was washed separately in running water and 100 grams of whole leaves blended with $500 \mathrm{ml}$ distilled water. The two different categories of leaves extracts obtained were filtered through a cotton cloth and concentrated to 20,10 and 5\% extracts as described by Chapla \& Campos, (2010).

\subsection{Germination Bioassays to evaluate the allellopathic effects of aqueous $P$. guajava leaf extracts on} germination rate, shoot and root length elongation of selected native species

Germination bioassays were carried out according to the method described by Chapla \& Campos, (2010) with slight modifications. Seeds of native tree species Cordia africana, Diospyros mespiliformis, Croton megalocarpus and Markhamia lutea were obtained from Kenya Forest Research Institute (KEFRI). Petri dishes 
Allellopathic potential of invasive Psidium guajava L. against selected native tree species in ..

and the cotton wool were sterilized in boiling water for a duration of 30 minutes to avoid contamination (Barbosa et al., 2008). Inside the petri-dishes absorbent cotton were evenly distributed on the surface and saturated with $2 \mathrm{ml}$ concentration of each of the extract $(20 \%, 10 \%$ and $5 \%)$ or distilled water $(0 \%)$ as control, respectively to see the response of seeds to extracts under various concentrations. The effect of the leaves extracts on germination, shoot and root length elongation of native species was conducted in a full randomized design with three repetitions for each treatments and control groups. Ten seeds of each species were placed in sterilized petri-plates that were $10 \mathrm{~cm}$ in diameter. The seeds were allowed to geminate in germination chamber at $30^{\circ} \mathrm{C}$ and 12-hour photoperiod. C. africana was subjected to germination duration of 60 days, M. lutea subjected to 30 days, D. mespiliformis subjected to duration of 30 days and C. megalocarpus subjected to 30 days. According to Bussmann \& Lange (2000), these are the duration that the respective certified seeds take to germinate and elongate their shoots and roots to measurable levels. New extracts were prepared after every 5 days and kept in a refrigerator for refilling the petri dishes. After the germination period for each respective tree seeds, germinated seeds were counted; and the root and shoot length of each measured using a caliper.

\subsection{Statistical analysis}

All the data was subjected to normality test before analysis. Since all the data displayed a normal distribution, a parametric test was used. SPSS, (Version 22) was used for analysis. One-way analysis of variance (ANOVA) was used to compare means and Tukey Post hoc test values were used to separate the significant different means at $\mathrm{p} \leq 0.05$.

\section{Results}

\subsection{Effects of aqueous $P$. guajava leaf extracts on germination rate of selected native species}

The results revealed that the green fresh leaves extract had a significant effect on seed germination of C. Megalocarpus $(F(3,8)=54.3 \mathrm{p}=0.001)$ and $C$. africana $(F(3,8)=27.7 \mathrm{p}=0.002)$. However, no significant inhibition was observed in M. lutea $(F(3,8)=2.8 p=0.11)$ and $D$. mespiliformis $(F(3,8)=3.1 \mathrm{p}=0.09)$ in comparison with the controls. The brown dry leaves extract also had significance impact on seed germination of C. megalocarpus $(F(3,8)=162.2 p=0.001)$ and $C$. africana $(F(3,8)=181.8 p=0.002)$ with no significant inhibition being observed in $M$. lutea $(F(3,8)=1.1 p=0.41)$ and $D$. mespiliformis $(F(3,8)=4 p=0.06)$. A tukey post hoc analysis revealed that most of the highest inhibition, in both green fresh and brown dry fallen leaves extracts were concentration dependent and were more effective at the highest concentration of $\mathrm{T} 1=20 \%$ (table 1 ).

Table 1: The effects of $P$. guajava leaf extracts on seed germination rate of four native tree species.

\begin{tabular}{|c|c|c|c|c|c|}
\hline & \multicolumn{4}{|c|}{ Treatments } & \\
\hline Guavas leaves & Plant species & T1 $(20 \%)$ & T2 $(10 \%)$ & $\mathrm{T} 3(5 \%)$ & T4 (control) \\
\hline \multirow{4}{*}{$\begin{array}{lll}\text { Green fresh leaves } \\
\text { extract }\end{array}$} & M. lutea & $6.00 \pm 1.0_{\mathrm{a}}$ & $7.00 \pm 1.0_{\mathrm{a}}$ & $7.67 \pm 0.6_{\mathrm{a}}$ & $7.67 \pm 0.6_{a}$ \\
\hline & D. mespiliformis & $5.67 \pm 1.2_{\mathrm{a}}$ & $6.67 \pm 0.6_{a}$ & $7.00 \pm 0.0_{\mathrm{a}}$ & $7.33 \pm 0.6_{a}$ \\
\hline & C. africana & $3.00 \pm 0.0_{\mathrm{b}}$ & $5.67 \pm 0.6_{a}$ & $6.33 \pm 1.2_{\mathrm{a}}$ & $7.67 \pm 0.6_{a}$ \\
\hline & C. megalocarpus & $0.67 \pm 0.6_{\mathrm{c}}$ & $1.33 \pm 1.2_{\mathrm{b}}$ & $1.67 \pm 1.5_{\mathrm{b}}$ & $7.77 \pm 0.6_{a}$ \\
\hline \multirow[t]{4}{*}{ Brown dry leaves } & M. lutea & $5.67 \pm 1.5_{\mathrm{a}}$ & $6.00 \pm 1.7_{\mathrm{a}}$ & $6.67 \pm 0.6_{a}$ & $7.81 \pm 0.6_{a}$ \\
\hline & D. mespiliformis & $4.33 \pm 0.6_{a}$ & $5.33 \pm 1.5_{\mathrm{a}}$ & $6.33 \pm 0.6_{a}$ & $6.67 \pm 1.3_{\mathrm{a}}$ \\
\hline & C. africana & $1.00 \pm 0.0_{\mathrm{b}}$ & $2.67 \pm 0.6_{b}$ & $3.00 \pm 0.0_{\mathrm{bc}}$ & $8.33 \pm 0.6_{a}$ \\
\hline & C. megalocarpus & $0.00 \pm 0.0_{\mathrm{c}}$ & $0.33 \pm 0.6_{c}$ & $0.67 \pm 0.6_{c}$ & $7.67 \pm 0.6_{a}$ \\
\hline
\end{tabular}

Mean values of germinated seeds are presented as mean \pm standard deviation per treatment. Means having different letters in the same column differ significantly from each other at $\mathrm{p}=.05$

\subsection{Effects of aqueous $\boldsymbol{P}$. guajava leaf extracts on shoot length elongation of selected native species}

The impact of green fresh leaves extracts on shoot length elongation of $C$. megalocarpus $(F(3,31)=57.1$ $p=0.01)$ and $C$. africana $(F(3,64)=4.0 p=0.02)$ was significant. The reduction in shoot length elongation of $M$. lutea $(F(3,82)=2.2 p=0.09)$ and $D$. mespiliformis $(F(3,76)=2.1 p=0.11)$ was not significantly different in comparison with the controls. The brown dry leaves extracts also exhibited a significant inhibition of shoot length elongation in $C$. Megalocarpus $(F(3,24)=401.49 p=0.001)$ and $C$. africana $(F(3,42)=40.71 p=0.001)$. Reduction in shoot length of $M$. lutea $(F(3,74)=1.54 p=0.21)$ and $D$. mespiliformis $(F(3,63)=0.77 p=0.516)$ were not significant. A tukey post hoc analysis revealed that inhibition in shoot length elongation, in both green fresh and brown fallen leaves extracts were concentration dependent and were more pronounced at the highest concentration of $\mathrm{T} 1=20 \%$ ( table 2 ).

Table 2: The effects of $P$. guajava leaf extracts on shoot length elongation of four native tree species.

\begin{tabular}{|l|l|l|l|l|l|}
\hline & \multicolumn{5}{|c|}{ Treatments } \\
\hline Guavas leaves & Plant species & $\mathrm{T} 1(20 \%)$ & $\mathrm{T} 2(10 \%)$ & $\mathrm{T} 3(5 \%)$ & $\mathrm{T} 4(\mathrm{control})$ \\
\hline \multirow{3}{*}{ Green fresh leaves extract } & M. lutea & $2.95 \pm 0.3_{\mathrm{a}}$ & $3.01 \pm 0.7_{\mathrm{a}}$ & $3.12 \pm 0.2_{\mathrm{a}}$ & $3.26 \pm 0.3_{\mathrm{a}}$ \\
\cline { 2 - 7 } & D. mespiliformis & $2.94 \pm 0.4_{\mathrm{a}}$ & $3.01 \pm 0.3_{\mathrm{a}}$ & $3.10 \pm 0.3_{\mathrm{a}}$ & $3.12 \pm 0.2_{\mathrm{a}}$ \\
\cline { 2 - 7 } & C. africana & $1.99 \pm 0.4_{\mathrm{b}}$ & $2.95 \pm 0.5_{\mathrm{a}}$ & $3.06 \pm 0.3_{\mathrm{a}}$ & $3.15 \pm 0.4_{\mathrm{a}}$ \\
\hline
\end{tabular}


Allellopathic potential of invasive Psidium guajava L. against selected native tree species in ..

\begin{tabular}{|l|l|l|l|l|l|}
\hline & C. megalocarpus & $0.55 \pm 0.5_{\mathrm{c}}$ & $1.43 \pm 0.3_{\mathrm{b}}$ & $2.35 \pm 0.7_{\mathrm{b}}$ & $3.11 \pm 0.2_{\mathrm{a}}$ \\
\hline \multirow{5}{*}{ Brown dry leaves extract } & M. lutea & $2.84 \pm 0.3_{\mathrm{a}}$ & $2.88 \pm 0.5_{\mathrm{a}}$ & $2.94 \pm 0.3_{\mathrm{a}}$ & $3.02 \pm 0.2_{\mathrm{a}}$ \\
\cline { 2 - 6 } & D. mespiliformis & $2.78 \pm 0.1_{\mathrm{a}}$ & $2.82 \pm 0.1_{\mathrm{a}}$ & $2.91 \pm 0.8_{\mathrm{a}}$ & $3.11 \pm 0.5_{\mathrm{a}}$ \\
\cline { 2 - 6 } & C. africana & $1.73 \pm 0.2_{\mathrm{b}}$ & $2.55 \pm 0.2_{\mathrm{a}}$ & $2.86 \pm 0.1_{\mathrm{a}}$ & $3.13 \pm 0.3_{\mathrm{a}}$ \\
\cline { 2 - 6 } & C. megalocarpus & $0.00 \pm 0.0_{\mathrm{c}}$ & $0.12 \pm 0.0_{\mathrm{b}}$ & $1.43 \pm 0.1_{\mathrm{b}}$ & $3.01 \pm 0.6_{\mathrm{a}}$ \\
\hline
\end{tabular}

Mean shoot length $(\mathrm{cm})$ of native species \pm standard deviation per treatment. Means having different letters in the same column differ significantly from each other at $\mathrm{p}=.05$

\subsection{Effects of aqueous $P$. guajava leaf extracts on root length elongation of selected native species}

The inhibition in rootlength elongation by green fresh leaves extract on C. megalocarpus $(F(3,31)=86.9$ $p=0.001)$, and $C$. africana $(\mathrm{F}(3,64)=46.3 \mathrm{p}=0.01)$, had similar patterns as the inhibition pattern observed in their shoot lengths elongations. They were significantly suppressed. The suppression by green fresh leaf extracts on M. lutea $(F(3,82)=1.4 p=0.26)$ and $D$. mespiliformis $(F(3,76)=1.2 p=0.31)$ were not significant. Brown dry fallen leaves extract had significant reduction in root length elongation of $C$. megalocarpus $(F(3,26)=86.6 p=0.001)$, C. Africana $(F(3,42)=4.9 \mathrm{p}=0.05)$, while no significant suppression was obseved in rootlength elongation of $M$. lutea $(F(3,74)=1.5 p=0.23)$ and $D$. mespiliformis $(F(3,63)=1.8 p=0.16)$. A turkey post hoc analysis gave the same results as those observed in shoot length elongation. Reduction in root length was concentration dependant and was most prominent at $20 \%$ concentration (table 3 ).

Table 3: Inhibitory impact of leaf extracts on root length elongation of selected native tree species

\begin{tabular}{|l|l|l|l|l|l|}
\hline & & \multicolumn{4}{|c|}{ Treatments } \\
\hline Guavas leaves & Plant species & $\mathrm{T} 1(20 \%)$ & $\mathrm{T} 2(10 \%)$ & $\mathrm{T} 3(5 \%)$ & $\mathrm{T} 4(\mathrm{control})$ \\
\hline \multirow{4}{*}{ Green fresh leaves extract } & M. lutea & $2.81 \pm 0.2_{\mathrm{a}}$ & $2.84 \pm 0.6_{\mathrm{a}}$ & $2.96 \pm 0.2_{\mathrm{a}}$ & $3.00 \pm 0.3_{\mathrm{a}}$ \\
\cline { 2 - 6 } & D. mespiliformis & $2.85 \pm 0.3_{\mathrm{a}}$ & $2.89 \pm 0.2_{\mathrm{a}}$ & $2.94 \pm 0.2_{\mathrm{a}}$ & $2.98 \pm 0.2_{\mathrm{a}}$ \\
\cline { 2 - 6 } & C. africana & $1.57 \pm 0.3_{\mathrm{b}}$ & $1.99 \pm 0.1_{\mathrm{b}}$ & $2.82 \pm 0.4_{\mathrm{a}}$ & $2.99 \pm 0.5_{\mathrm{a}}$ \\
\cline { 2 - 6 } & C. megalocarpus & $0.12 \pm 0.0_{\mathrm{c}}$ & $0.13 \pm 0.5_{\mathrm{c}}$ & $1.33 \pm 0.4_{\mathrm{b}}$ & $3.12 \pm 0.3_{\mathrm{a}}$ \\
\hline \multirow{5}{*}{ Brown dry leaves extract } & D. mespiliformis & $2.79 \pm 0.3_{\mathrm{a}}$ & $2.87 \pm 0.1_{\mathrm{a}}$ & $2.89 \pm 0.1_{\mathrm{a}}$ & $2.94 \pm 0.2_{\mathrm{a}}$ \\
& M. lutea & $2.74 \pm 0.2_{\mathrm{a}}$ & $2.81 \pm 0.5_{\mathrm{a}}$ & $2.89 \pm 0.3_{\mathrm{a}}$ & $2.93 \pm 0.3_{\mathrm{a}}$ \\
\cline { 2 - 6 } & C. africana & $1.80 \pm 0.4_{\mathrm{b}}$ & $2.16 \pm 0.3_{\mathrm{bc}}$ & $2.88 \pm 0.6_{\mathrm{a}}$ & $3.02 \pm 0.8_{\mathrm{a}}$ \\
\cline { 2 - 6 } & C. megalocarpus & $0.00 \pm 0.0_{\mathrm{c}}$ & $1.10 \pm 0.0_{\mathrm{c}}$ & $1.37 \pm 0.5_{\mathrm{b}}$ & $2.94 \pm 0.3_{\mathrm{a}}$ \\
\hline
\end{tabular}

Mean root length $(\mathrm{cm})$ of native species \pm standard error per treatment. Means having different letters in the same column differ significantly from each other at $\mathrm{p}=.05$

\subsection{Comparison of the inhibitory prospective of brown dry leaf and green fresh leaf extracts on seed germination.}

The inhibitory comparisons of the brown dry leaf and green fresh leaf extracts were analyses and the results revealed that there was significant difference among the two categories of extracts $(F(7,88)=10.12$ $p=0.01$ ). A post hoc, Tukey HSD analysis revealed that it was the brown leaf extract that had more inhibitory impact on the germination percentage of the four native plant species at $20 \%$ concentration (Figure 2).

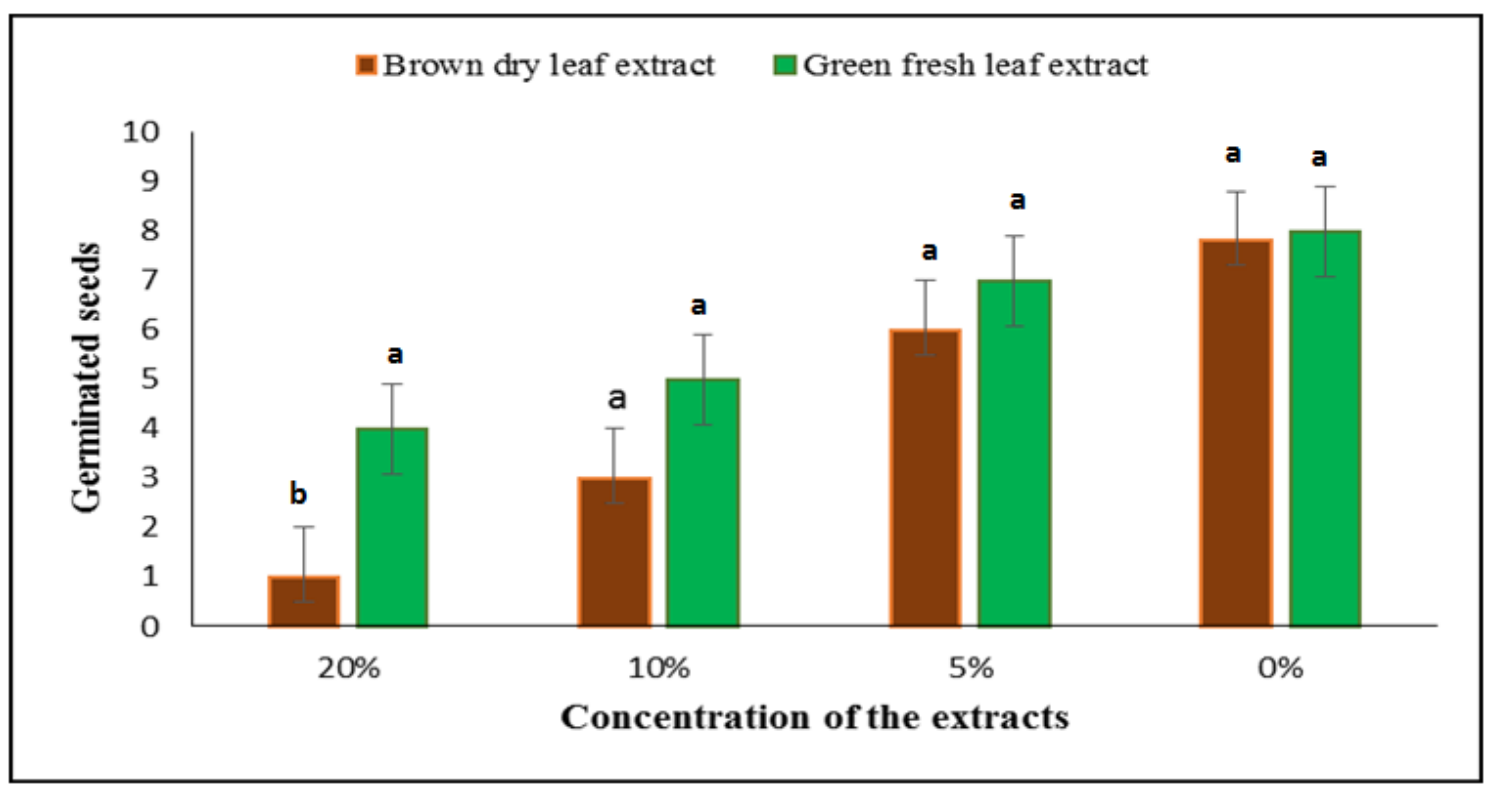

Figure 2: Inhibitory potential of the two leaf extracts. Error bars denote the standard deviation and the letters above the bars represent significant differences for one way ANOVA conducted for the particular extracts. 


\section{Discussion}

Based on the results, the allellochemicals inherent in P. guajava significantly inhibited the germination, shoot and root length elongation of some of the native plant species. These results were in agreement with the findings of Chapla \& Campos, (2010) who observed that the success of $P$. guajava in invading various ecosystems is partially attributed to the allelochemical inherent in it which suppresses, germination, growth and survival of other plant species. Previous studies on the chemical composition of $P$. guajava leaves have identified chemical products belonging to the groups with allelopathic properties such as terpenoids, coumarins, cyanogenic acids, flavonoids among others (Omeja et al., 2004; Khan et al., 2014). These allelochemicals inhibit seed germination and growth by blocking hydrolysis of nutrients reserve and cell division thus causing significant reduction in germination percentage and in the growth of plumule and radical of various plant species (Khan et al., 2014). In some cases, they change membrane permeability, interfere with chlorophyll formation, inhibit protein synthesis and inactivate the activity and functions of certain hormones and enzymes (Namkeleja et al., 2014).

P. guajava leaf extracts influenced the germination rate in M. lutea, D. mespiliformis, C. africana and C. megalocarpus in comparison with the controls. However, the influnce in C. africana and C. megalocarpus were siginificantly different. Seed germination is a complex process involving a set of morpohological, physiological and biochemical changes in a well defined manner (Tanveer et al., 2014). Any alterarion on the biochemical process by deficiency or excess of the chemical substances results into a disruption of the whole process. Namkeleja et al.,(2014) in his study of 'Allelopathic effects of Argemone mexicana to growth of native plant species' documented that during the process of seed germination, a rapid increase in glycolytic activity which is trigered by an increased rate of respiration is experienced. This process (Glycolytic activity) is necessary for the assemblage of stored carbohydrates to provide the seed with ATP and carbon products required for the biosynthesis of the radicles and plumule. However, these allellochemicals have been reported to have a mechanism of action and structural pattern similar to those of plant hormonoes (Isfahan \& Shariati, 2007). They also have acidic compounds which enables them inhibit the synthesis of Gibberellin (Einhelling, 1996). These properties make the allelochemicals to inhibit the actions of inducible hormones such as Gibberellin and the activities of specific enzymes such as amylases and Proteinases which are important for the process of germination (Isfahan \& Shariati, 2007). This could therefore be the reason for the significant reduction in germination of seeds in C. megalocarpus and C. africana. These results are consistent with the previous findinds of Sing et al.,(2002b) and Ashafa et al., (2012) where four monoterpenes and allelochemicals from Mangifera indica respectively significantly inhibited germination of Cassia occidentalis. In M. lutea and D. mespiliformis, reduction in seed germination rate were not significantly different with the controls. The chemical component which made them resistant to P. guajava leaf extracts were not investigated in this study. However, according to Inderjit et al., (2011), the secretion of oxalate has been documented to be the reason as to why some native plant species are able to resist suppressive impacts from the allellochemicals released by other species. The oxalate contributes to the resistance of the native plants by nuetralising the inhibitory effect of the allelohemicals. Incidences of some native plants resisting growth inhibition from extracts derived from invasive species have also been reported in other studies (Bruckner et al., 2003).

The results observed in rate of seed germination showed the same pattern as those in shoot and root length elongation. The shoot and root length elongations in C. megalocarpus and C. africana were siginificantly suppressed. Regulation of the concentrations of hormones such as auxins and gibberellins is essential for growth in plant cell and morphogenesis (Karuppanapandian et al., 2011). Most of the allelochemicals inherent in invasive species have been reported to disrupts hormone equilibrium (Namkeleja et al., 2014). This disruption is brought about by inhibiting polar auxin transport leading to a disturbance in normal auxin levels and resulting in the induction of lateral shoots and roots and subsequent suppression of growth (Brunn et al., 1992). Impaired metabollic activities induced by these allelochemicals also suppresses shoot and root length elongation (Ashafa et al., 2012). Ability of some native plant species to secrete oxalate as explained by Inderjit et al., (2011), could explain why the shoot and root length elongation in M. lutea and D. mespiliformis, were not significantly affected by the allelochemicals.

The inhibitory effect was concentration dependent and different species responded differently to the extracts. Such phenomena has been repoted by Siddiqui et al., (2009), Yarnia et al., (2009) and Ghorbanli et al.,(2011) where inhibition impact of various extracts of invasive species increased with increase in concentration. Among the two extracts, brown dry fallen leaves had a significant suppressive effect on the native species at $20 \%$ concentration than the green fresh leaf extracts at the same concentration. Ashafa et al.,(2012) attributes this to the fact that as leaves dry up, they pull together compounds (allelochemicals) that make them more suppressive. 


\section{Conclusion and Recommendations}

The results from this study reveal that the success of $P$. guajava in invading Kakamega forest, could be attributted partly to its allelopathic potential. The inhibitory effect on seed germination, root and shoot elongation was concentration depedent, where an increase in concentration caused an increase in inhibition. The brown dry leaf extracts had more inhibitory effect than the green fresh leaf extracts. $M$. lutea and $D$. mespiliformis were the most resistant plant species. Further Scientific studies are recommended to find out the chemical substances responsible for thier resistance. Planting such trees with high resistance to $P$. guajava inhibition in areas of the forest under heavy invasion could help mitigate successful invasion of $P$. guajava in Kakamega forest and other tropical forests with a view of minimizing its threat on biodiversity.

\section{Acknowledgement}

The authors are grateful to Mr. Peter Nyongesa, Laboratory technician at Masinde Muliro University of Science and Technology for his technical support in this exercise.

\section{References}

[1]. Althof, von A. J. (2005). Human Impact on Flora and Vegetation of In Memory of Prof . Dr . Clas M . Naumann. Unpublished Doctoral dissertation, Koblenz-Landau, Germany.

[2]. Ashafa, A. O. T., Ogbe, A. A., \& Osinaike, T. (2012). Inhibitory effect of mango ( Mangifera indica L .) leaf extracts on the germination of Cassia occidentalis seeds. african Journal of Agricultural Research, 7(33), 4634-4639.

[3]. Barbosa, E. G., Pivello, V. R., \& Meirelles, S. T. (2008). Allelopathic Evidence in Brachiaria decumbens and its Potential to Invade the Brazilian Cerrados. Brazilian Archives of Biology and Technology, 51(4), 825-831.

[4]. Brown, R.L., Tang, C. S. and Nishimoto, R. K. (1983). Growth-inhibition from guava roots exudates. Hortscience, 18, 316-318.

[5]. Bruckner DJ, Lepossa A, Herpai Z (2003). Inhibitory effect of Ragweed(Ambrosia artemisifolia L.) inflorescence extract on the germination of Amaranthus hypochondriacus L. and growth of two soil algae.Chemosphere 51:515-519.

[6]. Brunn, S.A., Muday, G.K. and Haworth, P. (1992) Auxin Transport and the Interaction of Phytotropins Probing the Properties of a Phytotropin Binding Protein. Plant Physiology, 98, 101-107.

[7]. Bussmann, R. W., \& Lange, S. (2000). Germination of Important East African Mountain Forest Trees Germination of Import ant East African. Journal of East African Natural History, 89(1), 101-111.

[8]. Chapla, T. E., \& Campos, J. B. (2010). Allelopathic Evidence in Exotic Guava ( Psidium guajava L .). Brazilian Archives of Biology and Technology, 53(6), 1359-1362.

[9]. Chollom, S. C., Agada, G. O. A., Bot, D. Y., Okolo, M. O., Dantong, D. D., Choji, T. P., ... Bigwan, E. I. (2012). Phytochemical Analysis and Antiviral Potential of Aqueous Leaf Extract of Psidium guajava Against Newcastle Disease Virus in ovo. Journal of Applied Pharmaceautical Science, 2(10), 45-49. doi:10.7324/JAPS.2012.21009

[10]. Ghorbanli, M., Gran A. and Zolfaghary A. (2011). The study of Allelopathic potential in three species of Glaucium Mill. On Sinapis arvensis L.Iranian Journal of Plant Physiology 2 (1): 321-324.

[11]. GISD-Global Invasive species database, (2010). Invasive species specialist group of the IUCN.

[12]. Inderjit, Wardle, D. A., Karban, R., \& Callaway, R. (2011). The ecosystem and evolutionary contexts of allelopathy. Trends in Ecology \& Evolution, 26(12), 655-662.

[13]. Isfahan, M. N., \& Shariati, M. (2007). The Effect of Some Allelochemicals on Seed Germination of Coronilla varia L . Seeds. American-Eurasian Journal of Agriculture and Enviroment, 2(5), 534-538.

[14]. Karuppanapandian, T., Moon, J.-C., Kim, C., Manoharan, K. and Kim, W. (2011) Reactive Oxygen Species in Plants: Their Generation, Signal Transduction, and Scavenging Mechanisms. Australian Journal of Crop Science, 5, 709-725.

[15]. Kawawa, R. C. ., Muyekho, F. ., Obiri, J. ., Agevi, H., \& Obiet, L. (2016). The Allelopathic Impact of Psidium guajava L, Leaf Extracts on the Germination and Growth of Cassia occidentalis L ., Seeds. IOSR Journal of Agriculture and Vetenary Science, 9(7), 101-105.

[16]. Kawawa, R. C. A., Obiri, J. F., \& Muyekho, F. N. (2016). The role of Psidium guajava L., seed bank asa strategy for its successful invasion of Kakamega Rainforest, Western Kenya. Asian Journal of Basic and Applied Sciences, 3(2), 1-6.

[17]. Kiefer, S., \& Bussman, R. . (2008). Household Energy Demand and its Challenges for Forest Management in the Kakamega Area , Western Kenya. A journal of plants, people and applied Research, 6, 363-371.

[18]. KIFCON - Kenya Indigenous Forest Conservation Programme (1994) Kakamega Forest: The Official Guide. Forest Dept., Nairobi. Kenya.

[19]. Kiplagat, A. K., Mburu, J., \& Mugendi, D. N. (2008). Consumption of non timber forest products ( NTFPs ) in Kakamega forest , Western Kenya. accessibility, role and value to resident rural households. In Biennial Internstion (pp. 1-28). A paper presented to the 2008 IASC Biennial International Conference 14-19 July 2008, University of Gloucestershire, Cheltenham, England.

[20]. Mammides, C., Cords, M., \& Peters, M. K. (2008). Effects of habitat disturbance and food supply on population densities of three primate species in the. African Journal of Ecology, 47, 87-96.

[21]. Mbuvi, M. T. E., J.O, M., P.O, O., C.K, K., R.A, O., \& J.K., M. (2009). Forest Management Buyangu Non- PFM area Adjacent Community: Print maxim. Nairobi, Kenya; Kenya Forest Research Institute

[22]. Namkeleja, H. S., Tarimo, M. T. C., \& Ndakidemi, P. A. (2014). Allelopathic Effects of Argemone mexicana to Growth of Native Plant Species. American Journal of Plant Sciences, 5, 1336-1344.

[23]. Naturwissenschaft, D. Der. (2011). Plant Communities , Species Diversity , Seedling Bank and Resprouting in Nandi Forests , Kenya. Unpublished Doctoral dissertation, University of Koblenz- Landau.

[24]. Obiri, J. A. F., Hall, J. B., \& Healey, J. R. (1998). Composition , Structure and Regeneration of Miombo Forest at Kitulangalo , Tanzania, 109-122.

[25]. Omeja, P., Obua, J., \& Cunningham, A. B. (2004). Regeneration, density and size class distribution of tree species used for drum making in central Uganda. African Journal of Ecology, 42, 129-136.

[26]. Ridenour, W. M., \& Callaway, R. M. (2001). The relative importance of allelopathy in interference: the effects of an invasive weed on a native bunchgrass. Oecologia, 126(3), 444-450. Retrieved from http://link.springer.com/10.1007/s004420000533 
[27]. Siddiqui, S., Bhardwaj, S., Khan, S.S., and Meghvanshi, M.K. (2009). Allelopathic Effect of Different Concentration of Water Extract of Prosopsis Juliflora Leaf on Seed Germination and Radicle Length of Wheat (Triticum aestivum Var-Lok-1), AmericanEurasian Journal of Scientific Research, 4 (2): 81-84.

[28]. Singh HP, Batish DR, Kaur S, Ramezani H, Kohli RK(2002b).Comparative phytotoxicity of four monoterpenes against Cassia occidentalis. Annals Appl. Biol. 141(2):111-116.

[29]. Tanveer, A., Sfdar, M. E., Tariq, M. A., Yasin, M., \& Noorka, I. R. (2014). Allelopathic Inhibition of Germination. Herbologia, 14(2).

[30]. Vuyiya, E., Martha, K., Harrison, T., Lenard, O., Charles, K., \& Humphrey, N. (2014). The impacts of human activities on tree species richness and diversity in Kakamega Forest, Western Kenya. International Journal of Biodiversity and Conservation, 6(6), 428-435. doi:10.5897/IJBC2014.0711

[31]. Wakjira, F. S. (2006). Biodiversity and Ecology of Afromontane rainforests with wild Coffea arabica L. populations in Ethiopia. Unpublished Doctoral dissertation, University of Bonn, Germany.

[32]. Yarnia, M., Khorshidi B., and Farajzadeh, M. T. E. (2009). Allelopathic effects of sorghum extracts on Amaranthus retroflexus seed germination and growth. Journal of Food, Agriculture \& Environment, 7: 770-774.

[33]. Zhao-hui, L., Qiang, W., Xiao, R., Cun-De, P., \& De-An, J. (2010). Phenolics and Plant Allelopathy. Molecules, $15,8933-8952$. 